\title{
anemon
}

Muş Alparslan Üniversitesi Sosyal Bilimler Dergisi

Journal of Social Sciences of Muş Alparslan University

Yı//Year: 2017 • Cilt/Volume: 5 • Sayı/Number: 2

ISSN: 2147-7655 • e-ISSN: 2149-4622

ÖZGÜN ARAŞTIRMA ○ ORIGINAL ARTICLE

\section{Kanaatin Veren Eli ile Kapitalin Homo Economicus'u Arasında Yaşanan Duygusal Salınımlar ${ }^{\text {a }}$}

\author{
Abdülcelil BİLGİN ${ }^{1, b}$ \\ ${ }^{1}$ Doç. Dr., Muş Alparslan Üniversitesi, İslami İlimler Fakültesi, Temel İslam Bilimleri Böl., Muş-Türkiye \\ Başvuru tarihi: 07 Mart 2017 Düzeltme tarihi: 20 Mayıs $2017 \quad$ Kabul tarihi: 28 Mayıs 2017
}

Öz

Kalkınma olgusu, genel olarak bir devletin gelir düzeyine paralel bir şekilde sosyoekonomik ve siyasi yapısında yaşanan pozitif değişimler olarak tanımlanabilir. Bu tanım, günümüzde daha çok tüketim olgusunu çağrıștırmakta hatta tüketim, kalkınmanın dinamosu olarak vaz geçilmez başat bir unsur sayılmaktadır. Tüketim olgusunun insanı getirdiği nokta ise herhangi bir kural ve ahlaki değer tanımayan Homo economicus olma durumudur. İslam, temelde iktisadi kalkınmaya karş1 olmamakla beraber, bu aşamaya geçişin bazı kural ve değerlere bağlı kalınarak sağlanabileceğine dair ölçüler koyar. Diğer bir deyişle, birey yahut devletlerin nasıl ve hangi ölçülere bağlı kalınarak kalkınabileceklerine dair perspektifler sunar. Bu çalışmada, inanan kişilerin, temel değerleri ile davetkâr karakterini büsbütün sergileyen kapital arasında yaşadığı gelgitler ele alınacaktır.

\section{Anahtar Kelimeler}

Kanaat, Homo Economicus, Kalkınma, Kapital, Tüketim

\footnotetext{
${ }^{a}$ Bu çalışma, 28-30 Eylül 2016 tarihlerinde Muş'ta düzenlenen ÜNİDAP Uluslararası Bölgesel Kalkınma Konferansı'nda sunulan tebliğin genişletilmiş formudur.

b Sorumlu Yazar/Correspoding Author: Muş Alparslan Üniversitesi, İslami İlimler Fakültesi, Temel İslam Bilimleri Bölümü, 49250, Muş / Türkiye.

e-posta: a.bilgin.deyim@gmail.com 


\title{
Sentimental Oscillations Taking Place between Contentment's Giving Hand and Capital's Homo Economicus
}

\begin{abstract}
The development case can be defined as positive changes in socio-economic and political structure of a state parallel to its income. This definition, rather, evoke the fact of consumption, furthermore the consumption is accepted as a basic factor of development. But this view of consumption leads people to be homo economicus who do not recognize any ethical values and rules. Though it is not basically opposed to economic development, Islam sets up some criteria to develop but this criteria are not indifferent to values and rules. In other words, Islam presents new perspectives showing which criteria and individual or a state should hang on. In this paper, it is studied on religious people's oscillations between their basic values and capital(ism)'s tempting character as a whole.
\end{abstract}

\section{Keywords}

Contention, Homo Economicus, Development, Capital, Consumption

\section{GİRIŞ}

Günümüzde birey ve toplulukların zihniyet, davranış ve görünüm gibi açılardan, diğer bir ifadeyle içsel ve dışsal özellikler yönünden gittikçe benzeştikleri söylenebilir. Artık birey ve toplulukları birbirinden ayıran din, mezhep ve etnik köken gibi unsurların, bağlılarını etkileme ve standardize etme noktasındaki başat rollerini, eskisinden farklı olarak yitirdikleri gözlenmektedir. Öyle ki günümüzde, özellikle kentlerde yaşayan insanların davranış ve duruşlarından hareketle ne düşündüklerini, neye inandıklarını anlamak neredeyse imkânsızlaşmıştır. Yani farklı inançlara bağlı insanlar arasında, adeta inançlar üstü bir gücün belirleyiciliği sayesinde meydana gelen benzerlikler söz konusudur. Bu tür benzeşmelerin diğer bir ifadeyle homojenleşme süreçlerinin toplumdan topluma, kişiden kişiye değişen birçok nedeni olmakla birlikte bunun başat itici gücünün, yerkürenin neredeyse tamamını kuşatan modernizm ve buna bağlı olarak gelişen modernleşme süreçleri olduğu tartışılmaz bir gerçekliktir. Bilindiği üzere modernizm, farklılıklara tahammül etmeyip onları ortadan kaldırmaya çalışan, herkesi ve her şeyi aynılaştırmak için her türlü yol ve yönteme başvuran bir sürecin adıdır. Daha açık bir ifadeyle modernizm, belirlemiş olduğu sınırlara dâhil olmayan ve kendini modern olandan farklı gören her şeyi/herkesi geri, eski ve ilkel kabul eder, ötekileştirir ve hayatın dışına itmeye çalışır.

Bilindiği gibi modernizmin en mühim itici güçlerinden ve aynı zamanda sonuçlarından biri kapitalist düşüncedir. Bireylerin, toplumların ve en nihayetinde hayatın aynılaşmasında küresel kapitalizmin rolü göz ardı edilemez. Kapitalizm, onun temel nitelikleri olarak belirlenen yoğun sermaye birikimi ve sürekliliği, kâr artırma ve büyüme 
zorunluluğu, pazar arayışı, yenilik üretme, uluslararası ekonomik ilişkiler, güçlü devlet, güçlü beşeri sermaye ile belirsiz ve kaygan ekonomik zemin arasındaki etkileşim örüntüleri tarafından belirlenen bir ekonomik sistem olarak tanımlanabilir. 16. yüzyılda Batı Avrupa'da ortaya çıkan ve giderek tüm dünyayı etkisi altına alan kapitalizmin küresel sonuçlarının her zaman var olduğu söylenebilir (Gençoğlu, 2012). Dünyaya hükmeden etkin lobilerin sonsuz desteğini arkasına alan küresel kapitalizmin hedefi herkestir. Ne kadar çok olursa olsun kazanılanı yeterli bulmayan, sürekli daha fazlasını, sadece kendisi için isteyen küresel kapitalizm; sınıf, cinsiyet, kimlik, din farkı gözetmeksizin herkes için rekabeti, kâr etmeyi, rasyonel davranmayı, parayı her şeyin değer ölçütü olarak kabul etmeyi, istediği her şeyi elde etmeyi vecibe haline getirmeyi amaçlar.

Küresel kapitalizmin kuşatıcı ve aşındırıcı etkisini, bireyden topluma hemen herkesin/kesimin farklı tonlarla hissettiği görülmektedir. Bu etkinin, birçok insani özelliğin aşınmasına, insanın doğal dengesini kaybetmesine; ülfet, merhamet, kanaat, cömertlik gibi değerlerin yerlerini düşmanlık, zulüm, aç gözlülük, bencillik gibi negatif davranışlara bırakmasına neden olduğu gözlenmektedir. Bu gözlem eğer doğruysa, insanların bir savrulma yaşadığı da doğrudur. Dolayısıyla bu konunun teoloji de dâhil olmak üzere sosyal bilimlerin farklı disiplinleri tarafından bütün açılarıyla etraflıca ele alınması kaçınılmaz bir gereklilik haline gelmektedir.

Yukarıdaki kaygılarla, insanın maruz kaldığı söz konusu değişim sürecinin inceleneceği bu çalışmada, öncelikle kanaat kavramı ve bu kavramın ahlak, zühd ve iffet ile ilişkisi üzerinde durulacaktır. Homo economicus'u ve onu ortaya çıkaran vasatı resmetmeye yönelik açılamalardan sonra, ideal İslam İnsan1/Müslüman ile Homo economicus arasındaki farklılıklar ele alınacaktır. Ardından kalkınma olgusu ele alınarak İslam'ın, kapitalizmin temel ilkelerinden olan kalkınma ve ilerleme karşısındaki tutumu tartışılacaktır. Bu çalışmada son olarak çağdaş Müslümanların temel değerleri ile kapital arasında takındıkları ikircikli tutumları ve çıkmazları ele alınacaktır.

\section{ETIMOLOJIK VE TERIM ANLAMLARIYLA KANAAT}

Kanaat kelimesi, Arapça kani'a/kana'a kökünden türemiş bir mastar olup bir şeye razı olmak, bir şey ile yetinmek; bir şeyden emin olmak; bir şeye kanaat etmek/getirmek; hoşnutluk, rıza gösterme, razı olma gibi anlamlara gelmektedir. Kelimenin anlam alanına dair şu bilgiler de önemlidir: Kanaat etmek, yetinmek, kâfi bulmak; kanaatkâr, elindeki ile yetinen, fazlasını istemeyen, kanaat sahibi; kanaatkârlık, elindekini kâfi görüp fazlasını istememe durumu (ez-Zemahşeri, 1992; Ayverdi, 2008). Yine bu kelimeden türemiş olan ikna (olmak) tabiri, inanmak, kanmak, kısmetine/payına razı olmak; ikna etmek ise, inandırmak, inanmasını sağlamak, kandırmak gibi anlamlara gelmektedir (Ayverdi, 2008). Başka bir deyişle kanaat, kişinin azla yetinip elindekine razı olması, gerek kendisinin gerekse sorumluluğu altında bulunanların ihtiyaçlarını asgari ölçüde karşılayabileceği maddi imkânlarla yetinip başkalarının elindeki şeylere göz dikmemesi, aşırı kazanma hırsından kurtulması şeklinde açıklanmakta; hırs, tamah, şereh (hazlara düşkünlük) ve tûl-i emel gibi kavramlarla ifade edilen dünyaya dair tutku ve isteklerin, iştahların kalpten silinmesiyle kazanılan ahlaki bir erdem olarak değerlendirilmektedir (Çağrıcı, DİA, 2001). 
İslam, İlahi takdir gereği her şeyde bir ölçü bulunduğunu, insanın Allah'1 unutmamak kaydıyla; onur ve emeğiyle dünyaya dair nasibini aramakla yükümlü olduğunu; kazancını Allah yolunda harcayarak cömert davranmasını; davranışlarında, hâl ve tavırlarında ölçülü olmasını ister. Ölçülü davranmanın yollarından biri de şüphesiz kanaatkâr olmaktır. Kanaat, İslam'ın temel kaynaklarının önemle üzerinde durduğu bir kavram/hazine olduğu gibi; kanaatkârlık övülen ve emredilen bir hâldir. Buna mukabil açgözlülük, hırs, tamah ve israf kötülenmiştir.

Kur'ân-1 Kerim'de bu kelime, mastar formuyla kanaat şeklinde geçmemekle beraber, kani'(Kur'an-1 Kerim, Hacc 22/36) ve mukni' (Kur'an-1 Kerim, İbrahim 14/43) şekillerinde yer alır. ayetteki kani' kelimesi, muhtaç olduğu için başkalarından maddi yardım beklerken, işi yüzsüzlük derecesine vardırmayan, bağışlanan şeye ve miktarına razı olan, (el-İsfâhâni, 2001) bir bakıma bu konuda iffetli davranan kişi anlamındadır. Kanaatkârlıkta izzet; dilencilikte zillet vardır, (ez-Zemahşeri, 1992) sözü bu durumu veciz bir şekilde tasvir etmektedir.

Kur'an'ın genel muhtevası göz önünde bulundurulduğunda mal, mülk vb. dünya metaına dair aşırı seviyedeki düşkünlüğün yerildiği görülmektedir. Öte yandan Peygamberimiz (sav)in de sözlerinde kanaatkârlığa vurguda bulunduğu görülmektedir. Hadislerde, Peygamberimizin kanaatkârlığı iffet, tok gözlülük ve gönül zenginliği olarak değerlendirdiği; (Buhari, Zekât, 1980; Müslim, Zekât, 1962) Müslüman olup sahip olduğu miktardaki rrzka kanaat eden kişileri övdüğü; (Ahmed b. Hanbel, 1995; Müslim, Zekât, 1962) asıl zenginliğin mal çokluğunda değil, gönül zenginliğinde olduğunu belirttiği (Buharî, Rikak, 1980; Müslim, Zekât, 1962) ve kanaatkârlığı şükrün en ileri derecesi saydığı (İbn-i Mace, Zühd, 1983) görülmektedir.

Kanaatkârlığın yeterli miktarın altındaki bir rızka da razı olmak anlamına geldiği ileri sürülmekle beraber, önemli olan elde edilen şeyin, miktarına bakılmaksızın, meşruiyet sınırlarında kazanılmış olması gerektiğidir. Yani önemli olan, kişinin meşruiyet dışındaki kazanımlara itibar etmeyerek, başkasının elindekine göz dikmeyerek helal dairesinde kazanç elde etmiş olmasıdır. Bu sınırlar çerçevesindeki kazancın miktarının ihtiyaçtan fazla olmasına engel bir durum yoktur (Çağrıcı, DİA, 2001). Çalışmayarak başkasının elindekine göz dikmek yerine, meşru sınırlar içinde bol miktarda kazanıp kazancını paylaşmak daha doğru olacaktır. Nitekim Maverdî, sonuçta fakirlik ve sefalete yol açacak bir kanaat anlayışını eleştirmiştir. Maverdî, sırf zengin olma hırsıyla davrananları, arzularını tatmin için aza kanaat etmeyenleri tenkit etmekte; ancak hem kendisine hem de başkalarına faydalı olmak gayesiyle ihtiyaç fazlası kazanç elde edenlerin takdir edilmesi gereken kimseler olduklarını belirtmekte; malın birçok iyiliğe vasıta, dine dayanak ve insanların kaynaşmasına yardımcı olduğunu ileri sürmektedir. Buradan hareketle Maverdî, kanaati üçlü bir formülasyonla izah eder: 1- En önemli derecesi, dünya nimetlerinden hayatın devamına yetecek kadarıyla iktifa edip fazlasını istememek. 2Gerekli miktara sahip olduktan sonra elinde arta kalan kısmına ilgi duymamak. 3- İmkân dâhilinde olanı istemek, elde edilmesi güç olan şeylerin peşinden koşmamak (Maverdî, 1978).

Ahlak ve adap ile ilgili eserlerde dikkat çeken bir husus, kanaatin ahlaki bir erdem olmasının yanı sıra insanın hem kişiliğini ve onurunu koruyup geliştirmesinin hem de mutlu ve huzurlu yaşamasının bir şartı olarak değerlendirilmesidir. Nitekim konu 
hakkında ilk müstakil çalışma olduğu anlaşılan İbn Ebi'd-Dünya'nın el-Kana'a ve'tTa'affüf isimli eserinin birinci bölümü, Başkasından Bir Şey İstemenin Kötülüğü, Bunun Engellenmesi ve $\mathrm{Bu}$ Konuda İffetli Olmanın Gerekliliği başlı̆̆ını taşır. Başka kaynaklarda da kanaatkâr olanın, onurlu ve özgür bir hayat süreceği, gönlünün huzura, bedeninin rahata kavuşacağı, kanaatle yaşayanın hayatı seveceği, heva ve hevesi terk edenin özgürleşeceği belirtilir. Başta Ya'kûb b. İshak el-Kindi'nin El-Hile Li-Def'i 1Ahzân'ı olmak üzere ahlak ve tasavvufa dair eserlerin çoğunda, üzüntü ve mutsuzluğun başlıca sebeplerinden birinin de kanaatsizlik olduğu bildirilmektedir (Çağrıcı, DİA, 2001).

\section{KANAAT-AHLAK İLISSKİSi}

İslam düşüncesinin bu iki önemli kavramı arasındaki yakın ilişki dikkat çekicidir. Ahlak kelimesinin anlamlarına dair verilecek bilgiler, onun kanaat ile ilişkisini ortaya koyacaktır. Ahlak, Arapça' da seciye, tabiat, huy gibi manalara gelen hulk veya huluk kelimesinin çoğuludur. Sözlüklerde çoğunlukla insanın fizik yapısı için halk, manevi yapısı için hulk kelimelerinin kullanıldığı kaydedilir (İbn-i Manzûr, 1984). Başta hadisler olmak üzere İslami kaynaklarda hulk ve ahlak terimleri genellikle iyi ve kötü huyları, fazilet ve reziletleri ifade etmek üzere kullanılmıştır. İslam dini, rekabet ve küçümseme duygusuyla geçici hazlara düşkünlüğün doğurduğu kaba ve hoyrat geleneklerin karşısına, insanın nefsini dizginlemesi, tabiatını öfke ve şiddetten koruması anlamına gelen hilm ve şefkati koymuştur. Bu suretle insana, o güne kadar başka varlıklara karşı yürüttüğü mücadeleyi, kendi nefsinin kötü temayüllerine yöneltmesi öğretilmiştir. Bu sebepledir ki Hz. Peygamber, tek olan Allah'a itaat temeline dayalı bir ahlaki ve dini birlik sağlama görevini üstlenmiş; (Kur'an-1 Kerim 3/103) böylece kabile ve soy sop anlayışı yerine; Allah'a sayg1, ferdi ve sosyal planda yücelmenin ve değer kazanmanın ölçüsü haline gelmiştir. Bu ölçüye uygun olarak İslam'ın öğretileri, bütün mahlûkata karşı merhametli olmayı, beşeri ilişkilerde dürüstlük ve güvenilirliği, karşılıksız sevgi ve fedakârlığı, samimiyet ve iyi niyeti, kötü eğilimlerin bastırılmasını ve daha birçok faziletleri ihtiva etmiş bulunmaktadır. İslam'ın öngördüğü ahlaki gelişimin ulaşacağı son nokta, kişinin çıkarlarına ilişkin kaygılarını aşarak pragmatik eğilimlerinden olabildikçe vaz geçmesidir (Çağrıcı, DİA, 1989).

Kuşkusuz Müslümanlar için her konuda olduğu gibi kanaatkârlık konusunda da en iyi örnek Peygamber' dir (SAV). Ebu Hüreyre, Hz. Peygamber'in arpa ekmeğiyle karnını doyurmadan bu dünyadan göçtügünü söyler (Buhari, Et 'ime, 1980; Müslim, Zühd, 1962; Ahmed b. Hanbel, 1995). Esasen dünyanın geçiciliği, asıl ve ebedi hayatın ölüm sonrasında başlayacağı şeklindeki İslami inancın sonucu olarak bu hayatın fani hazlarının ihtiyaçtan fazlasına önem vermek anlamsızdır. Kur'an-1 Kerim, İslam mücahitlerine fetihler sayesinde pek çok ganimet elde edeceklerini bildirmekteyse de (Kur'an-1 Kerim 48/19-20) Ahirette daha çok ganimet bulunduğunu hatırlatmaktadır (Kur'an-1 Kerim 4 / 94).

Asr-1 saadet'teki takva, züht, tevekkül, kanaatkârlık, fedakârlık gibi ahlaki erdemlere dayalı hayat anlayışı, zamanla yerini servet, şatafat ve gösteriş tutkusuna bırakmıştır. $\mathrm{Bu}$ olumsuz gelişmeler, başta Ebu Zer el-Gıfari, Ebu Musa el-Eş'ari, Abdullah b. Mes'ud, Selman-1 Farisi, Huzeyfe b. Yeman ve Ebu'd-Derda gibi sahabiler olmak üzere zahidane 
bir ahlaka eğilimli olanlar arasında ciddi hoşnutsuzluklara yol açmıştır (Çağrıcı, DİA, 1989).

Görünen o ki adı geçen sahabiler, kimilerinin kanaakârlık gibi bazı peygamberane tutumları terk etmesini, ahlaki bir yozlaşma olarak değerlendirmişler ve buna yönelik tepkilerini açık bir şekilde dile getirmişlerdir. Zira İslam ahlakına göre, gününü zevk ve sefa içinde geçirmek ya da bu gün adına rızık nedeniyle gereksiz endişelere kapılmak yerine, neticesi hayır olan işlere yönelmek gerekir. Bu ahlaki tavır, az ya da çok eldeki dünya nimetlerine karşı kanaatkâr olmayı gerektirecektir. $\mathrm{Bu}$ vesileyle, birbirini tamamlayan ya da biri diğerinin nedeni olan iki kavram olarak, kanaatkârlığın kişide ahlaki bir tutum olarak somutlaşması; ahlakiliğin de doğal olarak kanaatkâr olmaya yol açması gerekecektir.

\section{KANAAT-ZÜHD İLIŞKİsi}

Sözlükte zühd, bir şeye rağbet etmemek, ona karşı ilgisiz davranmak, ondan yüz çevirmek gibi anlamlara gelir. Malı az olan kişiye müzhid, az yemek yiyene zâhid, az olan şeye zehîd, dünyaya karşı perhiz hayatı yaşamaya zehâdet denir. Zühdün karşıtı rağbettir (İbni Manzûr, 1994; Ceyhan, DİA, 2013). Kur'an'da zühd kelimesi geçmez. Bununla birlikte, Hz. Yûsuf'u kuyudan çıkaranlar hakkında, ona fazla değer vermemeleri sebebiyle, zâhid kelimesinin çoğulu olan zâhidîn kullanılmıştır (Kur'an-1 Kerim, 12/20). Zühd kavramı, genellikle dünyaya karşı olumsuz tavır ve davranışların bütününü ifade eder. Dünya malına, makama, şöhrete önem vermemek; azla yetinmek; çokça ibadet etmek, ahiret için hayırlı işlere yönelmek gibi durumlar zühdün bazı göstergeleridir (İbn-i Manzûr, 1994). Zühd, dünya malına karşı kalpte duyulan soğukluk ve isteksizlik, maddeye sırt çevirmek, yasaklardan sakınarak vaktini ibadetle geçirmek; bir başka ifade ile dünya sevgisinden, madde hırsından, her türlü şehvetten uzak kalmak; ebedi mutluluk için vaktini ibadetle geçirmek gibi anlamlara gelir (Ceyhan, DİA, 2013; Akay, 1995). Nitekim ahiret hayatının dünya hayatından daha hayırlı olduğunu ifade eden ayetler, (Kur'an-1 Kerîm, 20/131; 28/60; 87/16-17) bâki olan âhiret hayatına yönelmenin kul için daha önemli olduğunu bildirmekte, insanın kalıcı ve sonsuz değerlere yönelmesini teşvik etmektedir. Dünyadan tamamen el etek çekip kendisini münzevi bir yaşama hapsetmeksizin sahip olunacak sahih zühd anlayışının, kanaatkârlığı ahlaki bir tutum haline getirmenin gerekliliğine işaret ettiği açıktır. Zira sahih bir zühd anlayışı, kişinin dünya malına karşı kalpte duyduğu soğukluk ve isteksizlik nedeniyle madde ile arasına anlamlı bir mesafe koymasına neden olacak, ihtiyacı kadarı ile yetinip fazlasını paylaşmasını sağlayacaktır. Başka bir ifadeyle, zühd kavramının telkin ettiği şeklide ihtiyaçtan arta kalanına fazla değer vermemek yani kanaatkâr olmak, Müslümanda alamet-i farika haline gelmesi elzem olan ahlaki bir tutumdur.

\section{KANAAT-İFFET İLIŞKİsi}

$\mathrm{Bu}$ iki kavram arasındaki ilişkiye geçmeden önce iffetin ne olduğu üzerinde durmak faydalı olacaktır. İffet, insanı bedeni ve maddi hazlara aşırı düşkünlükten koruyan erdem için kullanılan bir ahlak terimidir. Sözlükte, haramdan uzak durmak, helal ve güzel olmayan söz ve davranışlardan sakınmak anlamında mastar olan iffet kelimesi, daha çok 
ahlak kitaplarında ve bunların etkisinde kalan diğer eserlerde insandaki şehvet gücünün 1lımlı işleyişinden hâsıl olan erdemi ifade etmek üzere kullanılmış ve başta gelen faziletlerden biri kabul edilmiştir. Bu kaynaklardaki iffet tanımlarını; yeme, içme ve cinsi arzu konusunda ölçülü olmak, aşırı istekleri bastırıp dinin ve aklın buyruğu altına sokmak suretiyle kazanılan erdem şeklinde özetlemek mümkündür (Çağrıcı, DİA, 2000). İffetli kimseye afif denir. Kur'an-1 Kerim'de iffet kelimesi geçmemekle birlikte dört ayette aynı kökten isim ve fiiller yer almıştır. Bakara süresinin 273. ayetinde, mal yardımı yapılmasına en çok layık olan yoksulların özellikleri belirtilirken iffetli davranışları sebebiyle muhtaç olmalarına rağmen dilenmeyenlerden söz edilmektedir. Nur süresinin 32. ve 33. ayetlerinde, bekâr olup da evlenme vakti gelmiş olanları evlendirmeyi öğütleyen ayetin ardından, evlenme imkânı bulamayanlar ise Allah, lütfu ile kendilerini yeterli imkâna kavuşturuncaya kadar iffetlerini korusunlar, buyurulmuştur. İffetle ilgili ayetlerin ikisi, (Kur'an-1 Kerim, 2/273; 4/6) mal mülk, yeme içme konularında ölçülü ve kanaatkâr olmayı; diğer ikisi ise (Kur'an-1 Kerim, 24/33, 60) cinsel istekler hususunda ölçülü ve edepli davranmayı ifade etmektedir. Hadislerde, hem iffet kelimesine hem de aynı kökten başka kelimelere yer verilerek konu her iki açıdan ele alınmıştır. Mesela, Ya Rabbi! Senden hidayet, takva ve iffet diliyorum (Ahmed b. Hanbel, 1995) şeklinde dua eden Hz. Peygamber, Bakara suresinin 273. ayetini delil göstererek yardıma en layık olan kimselerin iffetlerini korumaya çalışan yoksullar olduğunu bildirmiş̧ir (Buhari, Tefsir, 1980; Müslim, Zekât, 1962). Diğer bir hadiste, Allah, yoksul olmasına rağmen iffetini korumaya çalışan mü'min kulunu sever, denilmiştir (İbn Mace, Zühd, 1983). Ahlak kitaplarında diğer temel erdemler gibi iffetten doğan tali derecedeki erdemler şöyle sıralanmıştır: Hayâ, mahcubiyet, müsamaha, sabır, cömertlik, işleri güzellikle ölçüp tartma, güler yüzlü, tatlı dilli ve kolaylaştırıcı olma, düzenlilik, güzel görünüş, kanaat, ağır başlılık, günahtan çekinme, yardımlaşma, kibarlık. Başta Kur'an-1 Kerim ve hadisler olmak üzere İslami kaynaklarda, olgun Müslüman sayılmak için sadece iman edip dinin bazı biçimsel kurallarını yerine getirmek yeterli görülmemiştir. İnsanın iffet, hayâ, edep, zühd, kanaat gibi faziletlerle donanmasının ve genellikle din bakımından günah sayılan, aklıselim sahibi insanlarca da ayıp ve kötü kabul edilen tutum ve davranışlardan uzak durmasının gerekliliği de vurgulanmıştır (Çağrıcı, DİA, 2000).

Gerek yukarıda naklettiğimiz ayet ve hadislerde gerekse ahlak ve adap ile ilgili eserlerde kanaatin ahlaki bir erdem, kişilik ve onuru korumak için vazgeçilmez bir unsur olarak değerlendirilmiş olması, hatta konuyla ilgili yazılan eserlerden birinin, kanaat ve iffet/elKana'a ve't-Ta'affüf (İbn Ebi'd-Dünya, 1993) şeklinde isimlendirilmiş olması ve bu kitaptaki bölümlerden birinin, Başkasından Bir Şey istemenin Kötülüğü, Bunun Engellenmesi ve $\mathrm{Bu}$ Konuda İffetli Olmanın Gerekliliği şeklinde adlandırılmış olması gibi eldeki bazı verilerden hareketle, kanaatkârlık ile iffet arasında yakın bir ilişki bulunduğu söylenebilir. Nitekim Bakara 2/273. ayetini de bu iki kavram arasındaki yakın ilişkiye işaret eden bir veri olarak değerlendirmek mümkündür: Bu ayette, özellikle bir sınıfa sadaka verilmesi tavsiye edilmektedir. Bu sınıf, zamanını dini hizmetlerle geçirdiğinden dolayı, doğal olarak geçimini sağlamaya yetecek rızkı temin için vakit bulamamaktadır. Buna rağmen nasip kısmet bulduğuna kanaat etmekte, iffetli olduğu için birilerinden bir şeyler istemekten uzak durmakta, bırakın inatla, ısrarla, arsızca bir şey istemeyi buna tenezzül dahi etmemektedir (Şimşek, 2012). Dolayısıyla kişinin çok zor şartlarda bile olsa kanaatkâr olması, son çare olarak birilerinden bir şeyler istemek 
zorunda kaldığında isteğini, onur, iffet ve kişiliğini zedelemeyecek ölçüler içinde; ısrar etmeden, arsızlık yapmadan, işi yüzsüzlüğe vurmadan dile getirmesi gerekmektedir.

Kanaat ve kanaatkârlığın İslam düşüncesindeki yeri ile ilgili olarak yukarıda belirtilen bilgileri şu şekilde toparlamak mümkündür: Kanaat sahibi olmak bir bakıma ikna olmaktır ki bunun birçok çeşit ve şeklinden söz etmek mümkündür. Kişinin rızkına kanaat etmesi, rızkının kendisine yeteceği konusunda ikna olduğunu; kişinin kendisine lazım olan şeylerin niceliğine kanaat etmesi, bunların dışında kalan şeylerin kendisini ilgilendirmeyeceği konusunda ikna olduğunu gösterir. Aslına bakılırsa kanaatin sadece, rızık, mal vb. maddi konularla ilgili olmadığı görülebilir. Kanaat, kişilerin hayatın her aşamasında kuşanması gereken bir zırh olarak değerlendirilebilir. Bilgi, ibadet, çalışma vb. maddi ve manevi konularda da kanaatin gerekli olduğu söylenebilir. Örneğin Peygamberimizin, her gün oruç tuttuğunu söyleyen bir sahabeyi bundan alıkoyduğu ve insanlara sadece ibadetle değil dünyevi işlerle de ilgilenmelerini tavsiye ettiği bilinmektedir (Müslim, Sıyam, 1962). Peygamberimizin bu tavsiyesi, ibadet konusunda da kanaatkâr davranmak gerektiğinin, bunun dışında kalan vakitleri çalışmaya, aileye, eşe, dosta ve akrabalara ayırmak gibi faydalı işlerle doldurmanın önemine işaret olarak algilanabilir.

İslam düşüncesinin önemli kavramlarından biri olarak kanaatkârlığın, Müslümanda/İslam insanında ahlak haline gelmesi gereken önemli hasletlerden biri olduğu açıktır. Tıpkı takva, sadakat, zühd, iffet, cömertlik, infak, diğergamlık gibi... Kanaatkârlığın doğuracağı en önemli sonuçlardan birinin cömertlik olacağı izahtan varestedir: Zira ihtiyaca yetecek miktarla yetinen kanaatkâr, zahid ve ahlaklı insan arta kalanını veren el olmanın erdemli tavrıyla hareket ederek veren elin alan elden üstün olduğunu kanıksamış olarak başkalarına dağıtacaktır.

Aslına bakılırsa kişinin kanaatkâr olup olmadığı daha çok ihtiyaç fazlası mal ve imkâna sahip olduğu zaman belli olur. Kanaatkârlıkla imtihan bu durumda daha ağır ve zor geçecektir. Zira geliri giderini ancak karşılayan kişinin kanaatkâr olması daha kolaydır. Çünkü o, giderini aşan bir gelire sahip değildir ve bu kişi eğer mümin ise doğal olarak içinde bulunduğu duruma isyan etmeyecek kanaatkârlı̆̆ı tercih edecektir. Asıl zor ama önemli olan şey giderinden fazla gelire sahip olanların kanaatkâr olabilmesidir. Kendisine ve ailesine yetecek miktarla iktifa edip arta kalanını paylaşıp bölüşen varlıklı kişinin gerçekten kanaatkâr olduğu anlaşılacaktır. Nitekim bu şekildeki bir kanaatkârlığın toplumsal yardımlaşmayı gerçekleştirmek konusunda daha işlevsel olacağı da açıktır. Zira fakirin kanaatkâr olması, ahlaki bir tutum olarak ve örneklik açısından güzel olmakla beraber, toplumsal fayda sağlama konusunda yeterli etki faktörüne sahip olmayacaktır. Dolayısıyla zengin kişideki kanaatkârlığın, ahlaki tutum ve örnekliğin yanı sıra zekât, infak ve sadaka gibi dinamikler sayesinde ihtiyaç fazlası varlığı dağıtarak toplumsal fayda temini noktasında daha işlevsel ve pratik değeri yüksek olacağını söylemek mümkündür.

Kanaatkârlığa dair bunca olumlu veri ve tasvirden çıkarılamayacak netice, İslam'ın çalışmayı önemsemediği, dünyadan tamamen el-etek çekmeye davet ettiği şeklindeki aşırı yorumdur. Tam da burada Maverdî'nin, sonuçta fakirlik ve sefalete yol açacak bir kanaat anlayışını eleştirdiğini ve bu bağlamda İslam'da çalışmanın ibadet olarak kabul edildiğini, Müslümanın bir işi bitince diğerine yönelmekle memur olduğunu, yeryüzünü 
imar, insanlığı sslah çabasından bir an bile geri durmaması gerektiğini, kanaatkârlığın atalet olmadığını hatırlamakta yarar vardır.

\section{HOMO ECONOMICUS'U DOĞURAN FELSEFİ, TOPLUMSAL VE TEOLOJIKK VASAT}

Gerek kanaat gerekse bu kelimenin ahlak, iffet ve zühd ile ilişkisi bağlamında ayet, hadis ve geleneğe referansla anlatılanlar dolayımında bir Müslümanın neden kanaatkâr olması gerektiği anlaşılabilecek bir durumdur. Peki, Batılı bireyi, Homo economicus bir varlığa dönüştüren saikler nelerdir? Homo economicus'un neliğine dair tanım ve tartışmalara geçmeden önce onu doğuran sürecin ve vasatın bilinmesinde yarar vardır. Zira bu varlık durup dururken ortaya çıkmış değildir. Batı'da, 16. yüzyılda başlayıp 19. yüzyılın başlarına kadar devam eden sürecin farklı kesitlerinde doğup yayılan Rönesans, Rasyonalizm, Hümanizm, Hedonizm, Aydınlanma, Sekülarizm, Deizm, Liberalizm, Kapitalizm, Klasik İktisat Teorisi gibi kavramların tamamı modernizmi doğuran yahut modernizmin doğurduğu olgu ve süreçler olup bunları incelemeksizin Homo economicus'u tanımak, anlamak ve anlamlandırmak mümkün olmayacaktır. Dolayısıyla anılan kavramlara dair yapılacak özlü açıklamalardan sonra, Homo economicus'u tanımak daha kolay olacaktır.

Rönesans: Bu kavram, klasik sanat ve edebiyat eserlerinin yeniden okunması şeklinde 14 . yüzyıldan itibaren İtalya'da başlayan ve zamanla tüm Avrupa'ya yayılan, sonuçta Ortaçağın kapanarak yeniçağın açılmasına neden olan tüm tarihsel ve düşünsel geliş̧melere işaret eder. Rönesans aynı zamanda tanrının merkezde olduğu bir evren tasavvurundan insanın merkezde olduğu bir evren tasavvuruna; dinsel rasyonalizmden seküler rasyonalizme; aşkıncılıktan dünyevileşmeye, bireyciliğe ve hümanizme, niteliksel ve tümdengelimci bir düşünme biçiminden niceliksel ve tümevarımcı bir yöntem anlayışına geçişi ifade etmektedir (Demir ve Acar, 1992). Rönesans düşüncesinin en temel özelliği, insanın her türlü bağlılıktan sıyrılmak suretiyle; kendisine dayanması, kendisini arayıp bulmasıdır. Bu nedenle, Rönesans düşüncesinde insan sorunu, önemli bir yer tutar. Bu sorun felsefede, hümanizm şeklinde karşıllk bulmuştur (Küçükalp ve Cevizci, 2010).

Aydınlanma düşüncesi: Geleneksel kozmoloji öğretilerinin yıkılmasına paralel olarak klasik felsefe anlayışının yerine geçen, geçmişten tamamen kopma iddiasındaki modern felsefe anlayış1, 16. yüzyıldan itibaren ortaya konan bilimsel başarılarla birlikte, 18. yüzyılda Aydınlanma düşüncesine vücut vermiştir. Bununla birlikte Aydınlanma, sadece düşünsel bir akım olmayıp bilimsel, kültürel ve toplumsal uzanımları da olan bir kavramı ifade eder. Aydınlanma, Avrupa'da 17. yüzyılın ikinci yarısıyla 19. yüzyılın ilk çeyreğini kapsayan bir döneme, ayrıca bu dönemi temsil eden birtakım düşünürlerin, akıl ve bilimi yegâne referans noktası kabul eden bir yaklaşım içerisinde insanı, bilginin ışı̆̆ıyla aydınlatma çabalarıyla öne çıkan kültürel bir döneme, bilimsel icat ve eleştiri çağına ve bu doğrultuda şekillenen felsefi ve toplumsal bir harekete gönderme yapar. İlk temsilcileri arasında Descartes ve Leibnitz'in bulunduğu Aydınlanma düşüncesinin en önemli temsilcileri Locke, Hume, Smit, Diderot, Helvétus, Montesquieu, Rousseau, Voltaire, Volf, Herder ve Kant’tır. Adı geçen bu düşünürler, düşünce ve ifade özgürlüğünü vurgulamaları, dine yönelik eleştirileri, akıl ve bilimin değerine duydukları inanç, sosyal 
ilerleme fikrine ve bireyciliğe verdikleri önem bağlamında, Aydınlanma hareketine katkıda bulunmuşlardır. Nitekim adı geçen düşünürlerin savundukları fikirler, modern toplumların ortaya çıkmasında büyük roller üstlenmiştir (Küçükalp ve Cevizci, 2010).

Aydınlanma hareketinin en belirgin karakteristiği, insan aklına duyulan yüksek güven ve ilerleme düşüncesidir. Aydınlanma, insanı köleleştirip tahakküm altına aldığı düşünülen hurafe, gelenek, mit gibi unsurlara karşı akli bir aydınlanmayı gerçekleştirme peşindedir. İnsanı eski düzenden kurtarıp daha iyi ve özgürleştirici olan aklın düzenine sokmak şeklinde tanımlanan aydınlanma, her türlü felsefi ve toplumsal düzeni, akla ve aklın ilkelerine dayandırır. İnsan aklı dışında, yaşamı biçimlendirip ona yön verecek hiçbir ilke ve değer tanımayan ve 17. yüzyılın başlarından itibaren Batı dünyasında egemen olan anlayış /Aydınlanma, din, mit ve geleneği bir kenara bıraktıktan sonra, insan ve doğayı ortak bir akıl paydasında birleştirerek, aklı nesnel bir bilgi kaynağı, insanı ise bu nesnel bilgi sayesinde evreni sınırsız bir şekilde dönüştürme yetkisine sahip bir varlık olarak görür. Çünkü Aydınlanma düşüncesi açısından ahlak, din ve politikaya dair sorunlarda en temel referans akıldır. Bu yüzden akıl, bütün inançları, kutsal metinleri, kanunları, sanat ürünlerini yargılar; ama kendisini yargılayabilecek her hangi bir kıstas yoktur. Kant'a göre insan, aydınlanma sayesinde olgunlaşarak, aklını kullanmayıp düştüğü çocukluk döneminden kurtulmuştur. 18. yüzyıl felsefesine, Aydınlanma Felsefesi; bu felsefenin hüküm sürdüğü zaman aralığına Aydınlanma çağı denilmesinin nedeni, söz konusu dönemde Batı dünyasında, dinin yol göstericiliğini reddeden, insani ilerlemenin ancak akıl ve bilim sayesinde gerçekleşebileceğini kabul eden aydınlanma düşüncesinin egemen olması ve bunun zihinsel dönüşümlere yol açmasıdır (Demir ve Acar, 1992; Küçükalp ve Cevizci, 2010).

Rasyonalizm ise, umumi manada aklın varlığını yahut önceliğini ve üstünlüğünü yani bilginin kaynağı olarak insan zihnini kabul ve müdafaa eden; insanın zihinsel faaliyetlerinin bağlı bulunduğu kurallarla nesnel dünyaya egemen olan kuralların aynı olduğunu; bu nedenle ancak aklın prensiplerine göre düşünerek gerçek, sağlam ve güvenilir bilgilere ulaşılabileceğini ileri süren; bütün açıklamaların odağına aklı ve akli prensipleri yerleştiren yaklaşım demektir. Bu yaklaşıma göre, Hegel'in deyimiyle, akla uygun olan her şey gerçek, gerçek olan her şey akla uygundur. Kısaca Rasyonalizm, us bilgisine dayanan, doğruluğun ölçütünü duyularla değil, düşünme ve tümdengelimli çıkarımlarda bulan öğretilerin genel adıdır (Bolay, 1990; Akarsu, 1988; Demir ve Acar, 1992).

Hümanizm: En genel anlamıyla bu kavram, hakikatin bilinmesinde referans olarak insan aklının merkeze alınması anlamına gelir. Hümanist felsefeye göre gittikçe yetkinleşen insan aklı, insani tercihler konusunda biricik referans kaynağı olmak durumundadır. Dolayısıyla insanın dünyayı anlamaya dair bütün faaliyetleri, duyusal verilere ve onların zihinle anlaşılmasına bağlıdır. Aşkın olanı, dini bilgiyi, hakikati test edecek hiçbir rasyonel ve bilimsel yol olmadığından; aşkın bir bilgi ve sezgi kavramı savunulabilir değildir. Bilgi diyebileceğimiz şeyin insani anlama alanına ait olması gerekir. Diğer bir ifadeyle hümanizm, İlahi nitelikte ve uhrevi olanın değil, bu dünya ve insanla ilgili olanın yüceltildiği eğilimin uç noktasını teşkil eder. Hümanizm, insanı, kendi üzerinde sınırlayıcı hiçbir otoriteye ihtiyacı olmayan, kendine yeterli, hakikatin yegâne ölçüsü ve kaynağı olarak kabul ederek onu, evrenin merkezine yerleştiren dünya görüşüdür (Demir ve Acar, 1992; Küçükalp ve Cevizci, 2010). 
Hedonizm: Yaşamın anlamını hazda bulan dünya görüşü olarak bütün ahlaki davranışların uygun sonunun mutluluk ya da haz olduğunu savunur. Hazzın mutlak anlamda iyi olduğunu, insan eylemlerinin nihai anlamda haz sağlayacak bir biçimde planlanması gerektiğini, sürekli haz verene yönelmenin en uygun davranış biçimi olduğunu savunur. Bu görüşe göre, haz veren şey iyidir, hatta haz ile iyi aynı şeydir; acı veren şey ise kötüdür (Gündüz, 1998; Akarsu, 1988; Demir ve Acar, 1992).

Deizm: Her türlü vahyi, ilhamı dolayısıyla vahyin bildirdiği Allah'1, dini, inkâr ederek sadece akıl ile idrak edilen bir Tanrının varlığını kabul eden bu görüş, peygamberlere ve dinlere ihtiyaç olmadığını ileri sürerek Tabii din fikrini benimseyip savunur. Daha açık bir ifadeyle bu görüsse göre, herhangi bir tanrıya inanılır; ancak akıl bunu kendi başına bilebileceği için vahye dolayısıyla peygamberlere gerek yoktur. Volter ve Rousseau bu anlayışa sahiptirler (Bolay, 1990; Demir ve Acar, 1992).

Sekülarizm: 1850'lerden itibaren kullanılmaya başlanan sekülarizm terimi, yaşamın tanrı, ahiret ve benzeri metafizik kavram ve değerlere dayalı inançlardan uzak şekilde yalnızca bu dünyayla ilgili prensiplere göre belirlenmesi anlayışını ifade eder. Din ve devletin ayrı ayrı özerk ve bağımsız olduğunu savunmayı esas alan sekülarizm, dünyevileşmeyi, sosyal hayatın dinsel dogma ve kurallardan bağımsız olması gerektiğini savunur. Batı düşüncesinde sekülarist düşüncenin temellerini Pavlus'un egemenlik anlayışına kadar götürmek mümkündür. Pavlus, tanrının egemenliğini sadece metafizik âlemle sınırlayarak kişinin, yaşamında içinde yaşadığı sosyal çevrenin egemen güçlerine mutlak itaat etmesi gerektiğini vurgular. Günümüzde bu kavram daha çok metafizikle ilişkili dinsel geleneklerin prensiplerini reddetmek ya da önemsememek anlamında kullanılmaktadır. Dolayısıyla sekülarizm, dinsel olan yahut dinsellik atfedilen bütün değer ve ilkeleri bireysel ve toplumsal yaşamın dışına iter, sadece bu dünyayı yaşanabilir kabul edip öte dünya ile ilişkisini koparma temeline dayalı insanmerkezci yaşam biçimini hedefler. Sekülarizm, semavi olanla bağların koparılmasını savunan bir ideoloji, insanı kendi kendine yeter kabul eden bir felsefedir (Gündüz, 1998; Demir ve Acar, 1992).

Klasik İktisat Teorisi: İktisadın felsefeden ayrılarak bağımsız bir disiplin haline gelmeye başladığı 18. yüzyılın sonları ile 19. yüzyılın başlarında ortaya çıkan iktisatçı düşünürlerin, iktisadi hayatın anlaşılması ve yorumlanmasıyla ilgili olarak ileri sürdükleri görüşlerden ve çözümlemelerden oluşan iktisat okuludur. Bu nazariye, merkantilizmin çöküşünden, 19. yüzyılın sonlarında müdahaleci ekollerin yeniden uç vermesine kadar geçen süreçte; iktisadi hayatta bireysel çıkar, serbest ticaret ve teşebbüsün esas kabul edildiği; ekonomiye devletin müdahale etmemesi gerektiğini savunan teori ve doktrinlerin tümüne işaret eder. Bu teorinin başlıca temsilcileri A. Smit, D. Ricardo, R. Malthus, J.B. Say, W. Senior ve J.S. Mill'dir. Bunlar, ekonominin fiyat mekanizması yoluyla kendiliğinden dengeleneceğini, bu dengenin her kes kendi çıkarının peşindeyken görünmez bir el tarafından sağlanacağını, ekonomiye müdahale edilmemesi halinde tüm toplumların refahını maksimum kılacağını savunmuşlardır (Demir ve Acar, 1992).

Liberalizm: Latince liber/özgür sözcüğünden türetilen liberal teriminin, Batıda 14. yüzyıldan beri; serf ya da köle sınıfından olmayan, entelektüel olarak bağımsız, geniş düşünceli, cömert ve hoşgörülü kişiler için kullanıldığı bilinmektedir. Liberalizm sanayileşmiş Batı toplumlarının ideolojisidir. Bu düşüncenin temel kaygısı, devlet otoritesine karşı bireye özgürlüklerini kazandırmaktır. Aydınlanma düşüncesinin 
etkisinde kalan ilk liberaller, insan doğasının iyiliğine ve rasyonel kararlar verebileceğine inanıyorlardı. Onlara göre, insanlar cezalandırılma korkusu olmadan inançlarına uygun biçimde özgürce yaşadıkları takdirde, kendi çıkarlarına sadık davranacaklardır. Liberalizmin en önemli ve değişmeyen tek ilkesi özgürlük olduğu için; devlet, toplum ve birey arasındaki ilişkilerde öncelik bireysel hak ve özgürlükler lehinedir. Aydınlanma düşüncesinin mirasçısı olarak Liberalizm, John Lock'tan, insanın özgürlük, eşitlik ve mülkiyet gibi doğal haklara sahip olduğu görüşünü almıştır (Karatepe, 2011).

Liberalizm, siyasi, iktisadi ve dini serbestlik; bireysel ve toplumsal özgürlük savunuculuğudur. Dolayısıyla kamu otoritesinin, ekonomik, sosyal ve dinsel süreçlere müdahil olmasına karşıdır. Bu çerçevede, devletin iktisadi hayata yönelik müdahale ve yönlendirmelerinin asgari düzeyde olması gerektiğini, piyasada oluşan arz ve talep mekanizmasının ekonomik ve sosyal açıdan en yararlı sonuçları yaratacağını ileri süren, bırakınız yapsınlar, bırakınız geçsinler ilkesini savunan öğretiye iktisadi liberalizm denir. Kamu otoritesinin bireylerin yaşamını yönlendirmesine ve sosyal yaşamı belirleyip sınırlamasına karşı çıkan; en iyi hükümetin en az hükmeden hükümet olduğunu savunan öğretiye ise siyasi liberalizm denir. Bu açıdan liberalizmi, kapitalizmin öncülü ve ilk kaynağı olarak görmek mümkündür. Bireyin, Ortodoks ve dogmatik görüşleri eleştirebilme, Hristiyan din adamlarına başkaldırabilme, onların düşünce ve uygulamalarını tenkit edebilme hakkına sahip olmasına ise dini liberalizm denir (Sezal, 1991; Demir ve Acar, 1992).

Kapitalizm: Servet ve sermayenin aynı ellerde toplanarak, sermayedar ile sermayeyi üretken hale getiren; işçilerin ayrı olduğu dolayısıyla olabildiğince sömürüldüğü, kapitalin merkezileşmesini esas kabul eden doktrine kapitalizm denir. Bu, birey ve üretici birimlerin, kişisel çıkarları doğrultusunda temelde kâr amacıyla iktisadi faaliyetlerde bulunduğu, özel mülkiyet ve hür teşebbüsün esas olduğu, üretimin pazara yönelik olarak yapıldığ 1 , her türlü mal ve hizmetin alım-satıma konu olduğu sosyo-ekonomik ve ideolojik sisteme işaret eder. Kapitalizm, 15. ve 16. yüzyıllardan itibaren Batıda feodalizmin yerine geçmeye başlayan, 18. ve 19. yüzyıllarda ise egemen iktisadi örgütlenme haline gelen, sermayenin hâkim olduğu toplumsal aşamadır. Sermayenin dayanışma, yardımlaşma ve merhamet gibi duygulara prim vermeyen acımasız ilkelerinin egemen olduğu kapitalist sistemde, neyin ne kadar, nasıl ve kimin için üretileceğine; gelir dağılımının nasıl olacağına piyasa mekanizması çerçevesinde çözüm bulunacağı ön görülür (Bolay, 1990; Demir ve Acar, 1992).

Modernizm: Bu kavram, modern dönemde ortaya çıan ve özellikle de 19. yüzyılda Batı dünyasında egemen hale gelen dünya görüşüne işaret eder. Bu bakımdan modernizm, modern dönemlerdeki yaşayış tarzının (modernlik) yanı sıra, kültürel gelişmeyi de (modernite) yansıtır. Başka bir ifadeyle modernizm, Aydınlanma çağının neden olduğu zihinsel dönüşümün, ortaya çıkardığı ideoloji ve yaşam biçimi olarak; hümanizm, sekülarizm ve demokrasiyi temel alan, egemenliği insana özgüleyen, kurtuluşu dinde değil bilimde arayan insan odaklı dünya görüşüdür. Kökleri, Antik Çağ felsefesine kadar uzanan modernizm, akılcı ve ilerlemeci bir bakış açısı taşıdığından bu yönüyle Aydınlanma felsefesine eklemlenmektedir. Modernizm, dinamik, değiştirici ve dönüştürücü karakterde olup aydınlanmış bireylerin inşa ettiği rasyonel bir dünya düzeninden yanadır. Modern kapitalist-endüstriyel devletin gelişimine paralel olarak ilerlemenin, ekonomik ve idari rasyonalizasyonun ve sosyal farklılaşmanın vuku bulduğu 
bir durumu ifade eden modernizm, yaşamı birey, eleştiri ve akıl kavramları üzerine bina ederek feodal toplumun mistik, geleneksel bağlarını çözmüş; bireyi ve aklını yücelten yeni bir toplumsal düzen kurmuştur (Yıldırım, 2009; Demir ve Acar, 1992; Günerigök, 2015).

Homo economicus'u doğuran felsefi, toplumsal ve teolojik vasatı, temelde üç kavrama indirgeyip bunlar üzerinden okumak mümkündür: Akıl, Özgürlük, Eleştiri. Söz konusu vasatta aklın en önemli değer haline geldiği, adeta kutsandığı anlaşılmaktadır. Öyle ki akıl, en yüce otorite olarak her şeyi; bütün kişi, kurum ve inançları yargılayabilecek bir konum elde etmiş; ancak kendisinin eleştirilmesi söz konusu dahi edilmemiştir. Zira bu vasatta, aklı eleştirebilecek ya da onu yargılayabilecek her hangi bir kıstasın olmadığına inanılmıştır. Özgürlük, kişilerin her türlü kutsalı, geleneği, değeri, otoriteyi mahkûm etmesine imkân veren bir enstrüman olarak kabul görmüştür. Akıl ve özgürlük gibi güçleri arkasına alan birey, doğal olarak eleştiriyi davranış haline getirmiştir. Bu olgular, sonraları inanç ve geleneklere karşı ihtiyatlı hatta çoğu zaman mesafeli, önyargılı ve şüpheci bir varlığın ortaya çıkmasına neden olmuştur. Ya tanrıya inanmayan ya da inandığı tanrıyı, bütün kudretinden soyutlayarak ona sınırlı bir alan tanıyan bu varlık, maneviyattan yoksun bir şekilde boy göstererek, hayatı bu dünya ile sınırlandırmış ve bütün enerjisini, ötekisine ilgisiz kaldığı bu dünyada nasıl daha mutlu olabileceğine, sınırsız kazanç sağlamaya, dilediği kadar tüketebilmeye harcamıştır. Söz konusu vasat, Dostoyevski'den ilhamla ifade edilecekse Tanrı yokmuş gibi davranan insanların çoğalarak zamanla her şeyi mubah görmesine neden olmuştur.

\section{HOMO ECONOMICUS / RASYONEL / İKTİSADİ İNSAN}

Latince olan bu deyim, sosyal bilimler literatüründe sık rastlanan kavramlardan biri olarak ekonomik / iktisadi insan anlamına gelmektedir. Bu tabir ile bütün davranış ve düşüncesini iktisadi menfaatlerine göre düzenleyen insan tipi kast edilmektedir. Bu tip, hayatı sadece üretmek ve tüketmekten ibaret görerek hiçbir ahlaki değer taşımamaktadır. Homo economicus, sanayi devrimiyle birlikte, bütün batıda ve sanayileşen toplumlarda görülen bir insan modelidir. İnsanı sadece ekonomik bir varlık olarak kabul eden, faaliyetlerinde menfaat duygusunu ve bireysel çıkarlarını her şeyden üstün tutan, daha çok kâr sağlamaya yönelik en uygun enstrümanları seçmeyi temel prensip haline getiren, yaptığı rasyonel tercihlerle tatmin düzeyini maksimumlaştırmayı hedefleyen, klasik iktisadi düşüncenin yarattığı, kafası ekonomik çıkarlara ayarlanmış Homo economicus modeli, şüphesiz materyalist felsefenin bir ürünüdür (Sezal, 1991; Demir ve Acar, 1992).

Öteden beri iktisat literatüründe insana dair farklı tanımlamalar yapılagelmektedir. Bunlardan bir tanesi de Rasyonel İnsan/Homo economicus tanımlamasıdır. Bütçe imkânları çerçevesinde refahını maksimize eden birey anlamına gelen Homo economicus, haz peşinde koşan ve elemden kaçan; tüketici olarak fayda maksimizsyonunu; üretici olarak ise kâr maksimizasyonunu önceleyen Rasyonel İnsanı tasvir eden bir tabirdir (Daric1, 2015).

Klasik iktisat teorisine göre yaşam, doğal seleksiyondan ibarettir ve bunun devamı için zayıfların bertaraf edilmesi lazımdır, zira bu dünyada onlara yer yoktur. Yine bu teoriye göre, doğa kanunları çerçevesinde hayat bir mücadele olup bu mücadelede bireysel haz 
ve maksimum tatmin esastır. Bu nedenle insanın, doyumsuz doğası gereği çıkarlarının maksimizasyonunu sağlamaya çalışması gerekecektir. Klasik iktisat teorisine göre bireyler arasındaki yaşam mücadelesinde kazanacak ve ayakta kalacak olan Homo economicus'tur. Homo economicus / Rasyonel İnsan varsayımı, 1848'de John Stuart Mill'in Essays on Some Unsettled Questions of Political Economy adlı çalışmasıyla ortaya konmuştur. 19. yüzyılın sonlarında Jevons, Walras ve Menger gibi Marjinalistler, Mill'in fikirlerini aksiyomlar halinde düzenlemişlerdir. Ben-Ner ve Putterman'ın deyimiyle Homo economicus, en iyi ihtimalle ahlak ile ilgisiz ve en kötü ihtimalle de bütünüyle faziletsizdir. O, kendisine menfaat sağlayacak hırsızlık, hilekârlık ve hatta cinayet gibi her türlü eylemde bulunabilir. Homo economicus'u bu eylemleri gerçekleştirme niyetinden vazgeçirebilecek tek şey cezalandırılma korkusu, gelecekteki iş kaybı ve istikbali ile ilgili birtakım başka kaygılardır. Literatürde öngörülen geleneksel iktisadın öngördüğü model olarak Homo economicus, inançtan arındırılmış bir pozitivist olarak rasyonel, tam bilgili, seçici, çıkarcı, doyumsuz, açgözlü, bencil, tutarlı, aldanmaz, daha fazlasını isteyen ve öngörü sahibi bir kişiliktir (Madi, 2014). Bu özellikleriyle Homo economicus, esas ideolojisi ve gayesi sürekli daha fazla kazanmak ve biriktirmek olan, bu uğurda her türlü sömürü ve yağmayı meşru sayan kapitalizmin bir şövalyesidir. Kapitalin doğasına uygun olarak Homo economicus'un artık bir noktada durması, elde ettikleriyle yetinmesi düşünülemez. Bunun nedeni, kapitalizmin sınırını belirleyen şeyin yine kendisi olmasıdır. $\mathrm{Bu}$ da herhangi bir sınır olmayacağı anlamına gelir. $\mathrm{Bu}$ sınırsızlıkta, artık iktisadi faaliyetler insani olmaktan çıkmıştır; Homo economicus, üretim ve kazanç arzusunun sürüklediği bir şizofreniye yakalanmış; adeta arzulayan bir makinaya dönüşmüştür (Özhan, 2005).

Yeri gelmişken şunu da belirtmekte yarar vardır: insanın Homo economicus bir varlık olduğuna dair söylem ve kanaatlerin yaygınlığına, başka bir ifadeyle iktisat biliminde insan, kabul görmüş bir yaklaşımla böyle bir isimlendirmeyle tanımlanmasına rağmen, onu bu şekilde tanımlamanın tartışmaya açık olduğuna dair görüşler de bulunmaktadır. Bu bağlamda ne Homo economicus'un ne de alternatif olarak sunulan rasyonel davranış modellerinin insan davranışlarını tam olarak tanımlayamadığı, insanın salt ekonomik varlıktan ziyade psikolojik bir varlık olduğu dolayısıyla davranışlarının belirli bir formülasyon dâhilinde ifade edilemeyeceği ileri sürülmektedir (Akyıldız, 2008).

\section{DİNLER VE HOMO ECONOMICUS}

Yukarıda temel özelliklerini saydığımız Homo economicus insan tipinin sadece İslam nazarında değil; diğer ilahi dinlere göre de olumsuz bir model olduğu söylenebilir. İlahi dinler, insanın bu dünyadaki eylem ve söylemlerinin ahiret hayatından bağımsız olamayacağını vurgularken, Rasyonel İnsanın bütün yapıp ettikleri bu dünyaya dairdir. İlahi Dinlere göre yerde ve gökte her ne varsa/mülk bütünüyle Allah'a ait iken, Rasyonel İnsan her şeyin sahibi olarak kendisini görür. İlahi Dinlere göre zengin-yoksul ilişkisinde gözetilmesi gereken yoksullardır. Oysa kapitalist Rasyonel İnsan yoksulu; ancak zenginliğini artıracak bir unsur olarak görür. İlahi Dinler, kural tanımaksızın elde edilen sınırsız zenginliği bir sapma olarak değerlendirir. Rasyonel İnsan ise zenginlikte sınır tanımaz ve bu yolda en ufak ahlaki bir kaygı bile taşımaz. İlahi Dinler aşağı yukarı aynı mesafeyle faize rezerv koyarken Rasyonel İnsan için faiz, zenginlik yolundaki en önemli ve vaz geçilmez kaynaklardan biridir (Madi, 2014). 
İlahi Dinlere göre insanın iktisadi yaşamdaki amacı, kendisini hedonistik zihniyete teslim etmek ya da sınırsız bir iktisadi özgürlük anlayışıyla arzularını tatmin peşinde koşmak değildir. İnsan, dünyaya maksimum haz elde etmek için gelmemiştir. Bu dinlere göre, başta insan olmak üzere kâinattaki her şey belirli bir amaç için yaratılmıştır. İnsan imtihandadır ve iyi ile kötü arasında tercihte bulunmakla karşı karşıyadır. O, iyi yahut kötü, yapacağ 1 tercihlere göre karşılık bulacaktır. Dolayısıyla yapacağı tercihler noktasında, ne Allah yokmuş gibi davranmalıdır ne de Ahireti unutmalıdır. Allah'ı ve Ahireti bir kenara bırakıp tercihlerini sadece bu dünyadaki yaşamını sağlama alacak şekilde yaptığında bunun sonucuna katlanacaktır (Madi, 2014).

Başta İslam olmak üzere İlahi Dinlerin, hiçbir kayıt, kural ve kutsal tanımayan, dünya ve dünyaya dair negatif kabul edilen unsurlardan arınma çabası içinde olmayan, kapitali tanrılaştıran Rasyonel İnsan modelini tasvip etmedikleri; aksine baştan sona ekonomik değil, maddeyle mananın dengede olduğu bir model peşinde oldukları rahatlıkla söylenebilir.

\section{HOMO ECONOMICUS ÍLE İSLAM INSANI ARASINDA BİR KARŞILAŞTIRMA}

Kapitalizmin idealize ettiği Homo economicus'un temel saiki kişisel menfaattir ve bunun somutlaşmış şekli burjuvadır. İslam'da ise toplum yararını kendi çıkarından üstün tutan, kanaatkâr insan tipi idealize edilmiştir. Bunun tarihteki en somut örneği, sadece ekonomik bir yapılanma olmakla kalmayıp dini ve kültürel boyutlarıyla toplumsal yaşama dair düzenlemeleri de hedefleyen Ahilik kurumudur (Tabakoğlu, 2010).

Homo economicus, sadece dünya hayatını dikkate alır, ahireti hesaba katmaz; İslam İnsanı, Ahireti hesaba katarak yaşar. Homo economicus, ihtiyaçların öncelik sırasını maddi olana verir, belki de sadece maddi ihtiyaçları vardır. Ona göre maddi ihtiyaçlarını gidermiş olmak, varlıklı olmak, saygın olmak için yeterlidir. İslam İnsanına göre ihtiyaçların sıralanması manevi olandan maddi olana doğru seyreder. Bu bağlamda saygın olmanız için varlıklı olmanıza gerek yoktur. Çok yoksul olabilir ama üst düzeyde toplumsal bir saygı ve sevgi görebilirsiniz. Çünkü İslam İnsanına göre, insanlar arası hiyerarşinin ölçütü manevi üstünlüklere sahip olmaktır (Özdemir, 2007).

Homo economicus maddiyata; İslam İnsanı hem maddiyata hem de maneviyata önem verir. Homo economicus'un ahlaki ve manevi değerleri yoktur; İslam İnsanı ahlaki ve manevi değerlere sahiptir. Homo economicus bencildir; İslam İnsanı sadece kendini düşünmez aynı zamanda diğergamdır. Homo economicus refahı kendisi için ister; İslam İnsanı, refahı toplumun tümüne yayma çabası içindedir. Homo economicus, kararlarının topluma etkisini göz önünde bulundurmaz; İslam İnsanı, kararlarının topluma olan etkilerini de dikkate alır, sosyal sorumluluğa sahiptir. Homo economicus, kendisi için sınırsız harcama yapabilir, sınırsız tüketme eğilimindedir, başkasına gelince cimridir; İslam İnsanı, aşırıya kaçmayacak biçimde ihtiyacı kadar harcama yapar, saçıp-savurmaz; ama cimri değildir. Homo economicus, kâr sağladığı sürece her alanda üretim yapar; İslam İnsanı dinin yasakladığı alanlarda üretim yapamaz. Homo economicus, üretim ve tüketime yönelik aldığı kararların çevreye olan etkilerini dikkate almaz; İslam İnsanı, çevreye zarar vermeyecek biçimde üretip tüketmeye çalısırr. Homo economicus, 
işlemlerinde güven unsuruna göre hareket etmez, güvenmez ve güven vermez; İslam İnsanı yaptığ 1 işlemlerde güven unsuruna göre hareket eder, güven beklediği gibi güven de sağlar. Homo economicus, sadece bu dünyayı hesaba katar, olayları sığ bir bakış açısıyla değerlendirir, faaliyetlerinin dış dünyaya olan etkisini hesap etmez; İslam İnsanı, bu dünya yanında ahireti de dikkate alır, olayları kapsamlı bir biçimde değerlendirir, faaliyetlerinin sadece kendisine değil dış dünyaya olan etkilerini de hesaba katar. Bu nedenle İslam İnsanının daha kuşatıc1, sorumlu ve rasyonel düşündüğü söylenebilir (Eren, 2013).

\section{0. İSLAM INNSANI/DÜNYASI VE KALKINMA: İMKÂN VE SINIRLAR}

Kapitalin sınırsız, kuralsız, ahlaksız kazanma hırsını kuşanmış Homo economicus'unun yönlendirdiği toplumların ekonomik kalkınmışlık düzeyi açısından ileride olacağı açıktır. Zira daha önce de belirtildiği üzere bu dünyada, her şey daha fazla kazanmak için kurgulanmış ve dizayn edilmiştir. Nitekim eldeki veriler de batılı toplumların kalkınmışlık düzeyi açısından hayli önde olduklarını göstermektedir. 2015 yılı itibariyle IMF verilerine dayanarak Gayrisafi Milli Hâsıla açısından dünya ekonomisine bakıldığında ilk yirmi ülkenin şu şekilde sıralandığg görülecektir: 1- Amerika Birleşik Devletleri, 2- Çin Halk Cumhuriyeti, 3- Japonya, 4- Almanya, 5- Birleşik Krallık, 6Fransa, 7- Hindistan, 8- Brezilya, 9- İtalya, 10- Kanada, 11- Güney Kore, 12- Avustralya, 13- Meksika, 14- İspanya, 15- Rusya Federasyonu, 16- Endonezya, 17- Türkiye, 18Hollanda, 19- İsviçre, 20- Suudi Arabistan (UPA, 2015).

Satın alma gücü açısından ise sıralama şöyledir: 1- Çin Halk Cumhuriyeti, 2- ABD, 3Hindistan 4- Japonya 5- Almanya 6- Rusya Federasyonu 7- Brezilya, 8-Endonezya, 9Birleşik Krallık, 10- Fransa, 11- Meksika, 12- İtalya, 13- Güney Kore, 14-Suudi Arabistan, 15- Kanada, 16- İspanya, 17- Türkiye, 18- İran İslam Cumhuriyeti, 19Avustralya, 20- Tayvan (UPA, 2015).

Yukarıdaki sıralamalara bakıldığında Gayrisafi Milli Hâsılaya göre ilk yirmi ülke arasında Hindistan, Endonezya, Türkiye ve Suudi Arabistan olmak üzere dört Müslüman ülke bulunduğu, bunlardan sadece yedinci sıradaki Hindistan'ın ilk on ülke arasında olduğu, diğer üçünün ise on altı, on yedi ve yirminci sıralarda olduğu görülecektir.

Satın alma gücü açısından yapılan sıralamaya bakıldığında ise Endonezya, Suudi Arabistan, Türkiye ve İran olmak üzere dört Müslüman ülkenin ilk yirmide yer aldığı, bunlardan sadece sekizinci sıradaki Endonezya'nın ilk onda olduğu diğer ülkelerin ise on dört, on yedi ve on sekizinci sıralarda olduğu görülecektir.

Birbirini besleyen her iki sıralamada da Müslüman olmayan ülkelerin hem çoğunluğu oluşturması hem de ilk sıralarda yer alması çeşitli şekillerde izah edilebilir. Bunlardan birisinin, kapitalist ve emperyalist Batı dünyasının karakteri gereği kalkınma, zenginleşme, sermayeyi belirli merkezlerde yığma konusunda hiçbir sınır tanımaması ve bu amaçla sömürgeci zihniyetini uygulamaya geçirmekten kaçınmaması, dahası bu gaye ile her yol ve yöntemi mubah sayması olduğu söylenebilir. Peki, bu durumda Müslüman ülkelerin geri kalmışlı̆̆ nasıl açıklanacaktır. Müslüman ülkelerin mevcut durumlarını, sadece Batının yukarıda zikrettiğimiz negatif karakteriyle açıklamak ne kadar objektif ve 
tutarlı olacaktır. Yoksa bu durum, İslam'ın kalkınmaya engel olduğu şeklindeki yaygın kanaatlerle mi izah edilecektir. Daha açık bir ifade ile İslam kalkınmaya/zenginleşmeye imkân tanımamakta mıdır?

Her şeyden önce şunu belirtelim ki İslam İktisadı, temelinde Kur'an ve Hadislerin bulunduğu ilkelere dayanmaktadır. Bu ilkeler, İslam İnsanının dilediği gibi davranarak yaratılış amacından uzaklaşmasına imkân vermez. Kulluk, belli yer ve zamanlara münhasır ritüellerle sınırlı olmayıp sürekli olarak iyilik peşinde olma çabası içinde olmaktır. Diğer bir ifadeyle kulluğu hayatın her alanına yayarak, hayatı topyekûn ibadet kıvamında yaşamaktır. Bu nedenle İslam, Kapitalin model insanı Homo economicus tipolojisine yabancıdır (Tabakoğlu, 2007).

İslam'da bireysel ve toplumsal kalkınmanın mümkün; ama bazı sınırlarla çevirili olduğu söylenebilir. Kalkınma, basit anlamıyla iktisadi bakımdan güçlü olmak şeklinde anlaşıldığında; her iki dünyada da insanlara mutluluk vaat eden İslam'ın onu göz ardı etmesi söz konusu olamaz. Başta yeryüzü olmak üzere bütün kâinat, insanın hizmetine verilmiştir. İnsanın, gerek görünür gerekse potansiyel olarak kullanımına verilen şeylerden yararlanabilmesi, bilimsel verilerden ve teknolojiden faydalanmasına bağlıdır. İslam İnsanı, meşru bütün imkânlardan yararlanarak iktisadi kalkınmayı gerçekleştirebilir. Dolayısıyla bu yolda elinden gelen her şeyi yapar ve Müslümanlığının gereği olarak tevekkül eder. Bu, Batı tarzı kalkınma anlayışından oldukça farklıdır. İslam İnsanı, çoğu zaman sonuç odaklı değil, süreç odaklı hareket eder. Önemli olan yolda olmaktır, menzile varılmasa da olur. Zira Allah, kişinin menzile varmak niyetiyle yola koyulduğunu/bu sürece girdiğini bilir, önemli olan da budur. Örneğin, İslam İnsanı, fakirliği ortadan kaldırılması gereken toplumsal bir sorun olarak görür, dahası fakirliğin kişilerde inanç sarsılmalarına yol açabilecek bir tehlike olduğuna dikkat çeker ve bu konuda insanlarda çeşitli duyarlılıklar oluşturur. Ancak İslam, herhangi bir kuraldan yoksun ve insanı salt iktisadi varlık olarak gören bir kalkınma modeli sunmaz. İslami anlayış, başkalarının durumlarını dikkate almadan, yalnızca kendini düşünerek, bencilce davranarak hiçbir ilke ve değer tanımadan ne pahasına olursa olsun maddi imkânlar elde etmeye karşıdır. İslam'ın öngördüğü kalkınma, ticari ilişkilerde yalana dayanmayan, kul hakkını kutsal kabul eden, sözüne ve sözleşmelerine bağli; tekelcilik, karaborsa, spekülasyon ve faize dayanan işlemlerle kişileri zarara uğratan şeylerin üretim ve ticaretinden ve israftan uzak, toplum menfaatini üstün tutan bir kalkınmadır. İslam'da işçi ile işveren diye iki ayrı sınıf bulunmadığından batıda olduğu gibi işçi sınıfı da yoktur. Zira İslami anlayış, sınıf temelli bir toplumsal hayatın teşekkülüne izin vermez. Dolayısıyla çalışma ve üretim süreçleri sadece zenginin lehine gelişmez. İslam'da Kapitalizmin en fonksiyonel gücü olan ve ekonominin motoru kabul edilen aşırı tüketim, çok açık bir ifade ile israftır (Hökelekli, v.d., 2006). İslam'da israf, faiz ve karaborsa yasağı; zekât ve infakın teşviki gibi ekonomik politikalar, sosyal adaletin ve adil gelir dağılımın finans kaynakları olarak kabul edilebilir. Kapitalistleşme sürecinin teşvik tedbirleri olarak kabul edilebilecek olan fakirden alıp zengine verme uygulamaları, hem teorik hem de tarihsel olarak İslam İktisadında söz konusu olmamış̧ır. Yine tekelci eğilimler engellenerek ve anti-enflasyonist para politikaları benimsenerek fiyat mekanizmasının toplumun refahını sağlamaya çalışması amaçlanmıştır (Tabakoğlu, 2010). 
İslam'da özel mülkiyet hakkı bulunmakla beraber bunun bazı sınılları vardır. Zira mülkün asıl sahibi Allah'tır. İnsanların mülkiyeti, Allah'ın mülkiyetinden türediği ve kendilerine bahşedilen bir emanet ve imtihan aracı (Kur'an-1 Kerim, 8/28, 3/186, 18/7, 45/22, 64/15) olduğu için, bireyler mülke gerçekten değil; ancak mecazen sahip olabilirler. Mecazen sahip oldukları mülkü toplum menfaatini tehdit edecek şekilde kullanamazlar; çünkü toplum ile bireyin menfaatleri çatıştığında, öncelikle toplumun hakları gözetilir. Özel mülkiyet bir hak olarak kabul edilmekle beraber kişiye, malında her dilediğini yapma hakk1 verilmemiştir. Mülkün yaygınlaştırılması, belli ellerde toplanmasının önlenmesi İslam iktisadının en önemli hedeflerindendir (Tabakoğlu, 2010).

Sonuç olarak İslam'ın kalkınmaya, zenginleşmeye, ilerlemeye karşı olmadığını, hatta bunları destekleyen temel dinamiklere sahip olduğunu; ancak gerek bireysel gerekse toplumsal ilerlemenin bazı dini, ahlaki, hukuki vb. kayıtlarla sınırlandırıldığını söylemek mümkündür. Zira İslam İnsanının en önemli özelliklerinden biri, zekât, infak, sadaka vb. temel umdelerden dolayı sahip olduklarını paylaşmaktır. Söz konusu paylaşma olgusu, sadece Müslüman bireyler için değil, İslam toplumları/devletleri için de yerine getirilmesi gereken bir görevdir. Yani Müslüman birey, her şeyden önce servetin temerküzüne karşı olduğu ve kendisini bütün insanlığa karşı sorumlu hissettiği için, sahip olduklarını başkalarıyla paylaşırken Müslüman toplumlar da aynı saiklerle zenginliklerini yeryüzünün herhangi bir yerinde yaşayan muhtaçlarla paylaşırlar. Bu durum tek başına bile bireysel ve toplumsal zenginliğin sınırsız ve kayıtsız olamayacağının garantörüdür. Dolayısıyla fakir, muhtaç ve mazlumların gözetilmesini önceleyen; adaleti tesise önem atfeden ve servet bölüşümünü telkin eden temel bazı İslami ilke ve prensiplerin; bütün zenginliğin, refahın, kalkınmanın sadece bazı birey ve toplumlarda temerküz etmesine engel olduğunu söylemek mümkündür. Bu bağlamda Müslümanlar, üzerlerine düşen her şeyi yerine getirip en zengin ve kalkınmış birey ve toplumlar haline gelseler bile Batı'da olduğu gibi servetin kendilerinde temerküz etmesini sağlayamayacaklardır. Bu dinen imkân dâhilinde olmayan bir durumdur. Ancak Müslümanların uzun zamandır içinde bulunduğu yoksulluğun nedeninin, İslam'ın zenginliğin temerküzüne karşı beslediği mesafe olmadığını hatırlatmakta da yarar vardır. Savunduğumuz şey, İslam'ın teori ve tarihsel pratikler açısından ahlaki ve adil bir kalkınmaya engel olmadığıdır.

\section{SONUÇ YERİNE: ÇAĞDAŞ MÜSLÜMANIN DİLEMMALARI}

Çalışmanın başından beri İslam insanı ile İktisadi insana dair özellikler zikredilmekte, çeşitli karşılaştırma ve değerlendirmelerde bulunulmakta, neticede İslam insanının pozitif özelliklerinden dolayı daha ideal bir tipoloji; İktisadi İnsanın ise negatif sayılan özelliklerinden dolayı kusurlu bir tipoloji olduğu ifade edilmektedir. İslam inancına göre böyle bir iddiada bulunmanın her hangi bir sakıncası yoktur. Ancak konuyu aktüel yönleriyle tartışmamanın çalışmayı eksik bırakacağı pek ala düşünülebilir. Bu nedenle işe çok güncel bir soru ile başlamak faydalı olacaktır: Günümüzün çağdaş Müslümanları, tarihsel tecrübe ve pratikleriyle örtüşmeyecek şekilde; hâl, hareket, tavır, eylem; düşünce, duygu, yaklaşım, eşyaya, tabiata ve olaylara bakış açısı vb. konularda birer İslam İnsanı mıyız yoksa Homo economicus mu? Tam olarak bunlardan hiç biri değilsek ve muhatap olduğumuz bu soru zorsa yumuşatarak benzer şeyler sorabiliriz. Günümüzün biz Müslümanları, İslam İnsanına mı yoksa Homo economicus'a mı daha yakınız yahut bunlardan hangisine daha çok benzemekteyiz? 
Çağdaş Müslüman, kanaatkârlık, diğergamlık, tutumluluk, cömertlik, şahsiyet, ahireti dünyaya tercih, toplumu bireye öncelemek, güvenilir olmak gibi İslam insanında bulunması gereken özellikleriyle mi öne çıkmaktadır; yoksa doymak bilmemek, açgözlülük, bencillik, müsriflik, cimrilik, maddiyata düşkünlük, makam, mevki ve zenginliğe karşı zaaf, dünya hayatına aldanma, maddeyi kutsama, refah ve zenginliğe düşkünlük, verilen kararlarda sadece kendini düşünme gibi Homo economicus'a ait özelliklerle mi öne çıkmaktadır? Çağdaş Müslüman, bireysel kalkınma sürecinde hangi ilkeleri esas almaktadır. Kendisiyle beraber başkalarını da kalkındırmak gibi bir amaç ve perspektifle mi davranmaktadır yoksa Homo economicus gibi bencilce ve faydacı mı? Yukarıda iki grup halinde zikredilen özelliklerden hangisi Çağdaş Müslümanda daha çok bulunmaktadır? Bütün bu soruların günümüz Müslümanına sorulması gereken esaslı sorular olduğunu düşünmekteyiz. Zira aktüel durum, Müslümanların tercih ve yaşantıları noktasında birçok dilemma ile karşı karşıya olduğunu göstermektedir. Çağdaş Müslümanın bulunduğu yer itibarı ile İslam İnsanına mı Homo economicus'a mı daha yakın olduğu konusu tartışmaya açıktır. Bu konuda, farklı veri toplama tekniklerinin uygulanmasıyla elde edilecek sonuçların kimileri için şaşırtıcı, kimileri için ise malumu ilam kabilinden olması mümkündür. En azından peşinen söylenebilecek şey, Çağdaş Müslümanın, hangi değerleri tercih ettiği ve edeceği noktasında çelişkiler yaşadığı, bir bakıma cami ile kilise arasında salınıp durduğudur.

Çalışmamızı, yukarıdaki soruların cevaplarını bulmaya katkı sunabileceği varsayımıyla tabi ki eleştiriye açık- bazı tespitlerle bitirmek faydalı olacaktır: Son çeyrek yüzyıldır küreselleşme ve neo-liberal politikaların etkisiyle Müslümanların da birey, toplum ve ülkeler bazında kalkınma ve ilerleme adı altında kapitalist dünyaya eklemlendiği iddiaları yaygınlaşmaktadır. Çağdaş Müslümanların, kentsel dönüşüm politikalarından tutun alışveriş alışkanlıklarına kadar homo economicus insanıyla benzeştikleri, birçok İslam ülkesinde bu eğilimin devlet ve hükümet politikalarıyla desteklendiği; kanaat, zühd, bereket, helal, gibi kavramların nerdeyse unutulduğu; israfin ihtiyaç diye tedavüle sokulduğu görülmektedir. Müslüman dünyanın içine düştüğü bu durum piyasa İslam'1, proje İslam'1, burjuva İslam'1, refah teolojisi gibi isimlerle eleştiriye tabi tutulmakta ve kapitalist dünyanın içine giren Müslümanlar, part-time Müslüman olarak adlandırılmaktadır. Moda, defile, marka tutkusu, İslami müzik gibi öykünmeci bir yaşam üzerinden Müslümanların, aslında karşıtlarıyla benzeştikleri iddia edilmektedir (Haenni, 2014).

\section{KAYNAKÇA}

Akalın, H.Ş. (2009). Türkçe Sözlük. Ankara: Türk Dil Kurumu Yay.

Akarsu, B. (1988). Felsefe Terimleri Sözlüğü. İstanbul: İnkılâp Kitabevi.

Akay, H. (1995). İslami Terimler Sözlüğü. İstanbul: İşaret Yay.

Akyıldız, H. (2008). Tartışılan Boyutlarıyla Homo economicus. Süleyman Demirel Üniversitesi İ̈BF Fakültesi Dergisi, 13(2), 29-40.

Arslan, A. (2010). Nehri Geçerken. İstanbul: Beyan Yayınları. 
Arslan, A. (2012). Sabra Davet Eden Hakikat. İstanbul: Pınar Yayınları.

Arslan, A. (2013). Yeni Bir Anlam Arayışı. İstanbul: Bilge Adamlar.

Arslan, A. (2015). Modern Dünyada Müslümanlar. İstanbul: İletişim Yayınları.

Ayverdi, İ. (2008). Misalli Büyük Türkçe Sözlük. İstanbul: Kubbealtı Yay.

Bolay, S. H. (1990) Felsefi Doktrinler Sözlüğü. Ankara: Akçağ Yay.

Buharî, Ebu Abdillah Muhammed, b. İsmail (1980). el-Camiü'-Sahih, Kahire: El Matbaatu's-Selefiyye.

Ceylan, S. (2013). DİA, Diyanet İslam Ansiklopedisi. İstanbul: DİA.

Çağrıcı, M. (2000). Diyanet İslam Ansiklopedisi, İstanbul: Türkiye Diyanet Vakfı Yay.

Çağrıcı, M. (2001). Diyanet İslam Ansiklopedisi, İstanbul: Türkiye Diyanet Vakfı Yay.

Çağrıcı, M. (1989). Diyanet İslam Ansiklopedisi, İstanbul: Türkiye Diyanet Vakfı Yay.

Darıcı, B. (2015). Sürdürülebilir Kalkınma, Yavaş Şehir (Cittaslow) Anlayışı; Rasyonel Insan'in (Homoe conomicus) Yeniden Sorgulanmast. Uluslararast Sosyal Araştırmalar Dergisi, 8(40), 641-647.

Demir, Ö., \& Acar, M. (1992). Sosyal Bilimler Sözlüğü, İstanbul: Ağaç Yay.

Doğan, A. (2006). Osmanlı Aydınlarl ve Sosyal Darwinizm. İstanbul: İstanbul Bilgi Üniversitesi Yayınları.

Eren, İ. (2013). İslam'ın Ekonomik Yapısında İnsan Modeli: Homo economıcus İle Karşılaştırmalı Bir Değerlendirme. Süleyman Demirel Üniversitesi IIBF Dergisi, 18(1), 367-384.

Gençoğlu, A. Y. (2012). Kapitalizmin Temel Nitelikleri Açısından Emeğin Konumu. HAK-ISS Uluslararası Emek ve Toplum Dergisi, 1(1), 98-116.

Gündüz, Ş. (1998). Din ve Inanç Sözlüğ̈̈. Ankara: Vadi Yay.

Günerigök, M. (2015). Risk Toplumu ve Din (Sosyolojik Bir Inceleme). Doktora Tezi. Kayseri: Erciyes Üniversitesi.

Haenni, P. (2014). Piyasa Íslam' 1 : Islam Suretinde Neoliberalizm. Ankara: Heretik Yayınları.

Hanbel, Ahmed b. (1995). Müsned. Beyrut.

Hökelekli, H. (2006), İslam 'a Giriş. Ankara: Diyanet İşleri Başkanlığı Yay.

İbn Ebü'd-Dünya (1993). el-Kana'a ve't-ta'affüf, Beyrut.

İbn-i Mace, Ebû Abdillâh Muhammed b. Yezîd el-Kazvînî (1983). es-Sünen, Riyad.

İbn-i Manzur, Ebu'l-Fadl Cemalüddin Muhammed b. Mükerrem (1994). Lisanü'l-Arab, Daru'l-Fikr, Beyrut.

İsfâhâni, Rağıb (2001) el-Müfredât fi Ğaribi'l-Kur'ân, Beyrut. 
Karatepe, Ş. (2011). Siyasi İdeolojiler. İstanbul: İz yayınc1lık.

Küçükalp, K., \& Cevizci, A. (2010). Batı Düşüncesi: Felsefi Temeller. İstanbul: İSAM Yay.

Madi, İ. (2014). Ortadoğu Dinleri Açısından Homo economicus'un Analizi. Doktora Tezi. İstanbul: Marmara Üniversitesi.

Maverdî, (1978). Edebü'd-dünya ve'd-din, Beyrut.

Müslim (1962). el-Câmiu's-Sahih, Kahire.

Özdemir, Ş. (2007). Din-Ekonomi İlişkisi ve Güncel Arayışlar. Ondokuz Mayls Üniversitesi Illahiyat Fakültesi Dergisi, 23(23), 153-164.

Özhan, T. (2015). "Homo Economicus" ve Hakikat. (Erişim: 09.08.2016), https://www.setav.org/homo-economicus-ve-hakikat/

Sezal, İ. (1991). Sosyal Bilimlerde Temel Kavramlar. Ankara: Akçağ Yay.

Şimşek, S. (2012). Hayat Kaynă̆ı Kur'an Tefsiri. İstanbul: Beyan Yay.

Tabakoğlu, A. (2007). İslam Ekonomisinin Tarih Boyunca Oluşturduğu Temel Kurumlar, Çağımızda Sosyal Değişme ve İslam, (s. 494-504), Ankara: Türkiye Diyanet Vakfi.

Tabakoğlu, A. (2010). Bir İlim Olarak İslam İktisadı. İslam Hukuku Araştırmaları Dergisi, 16.

Tirmizî (1962). el-Câmiu's-Sahih, Kahire.

UPA (2016). Dünya Ekonomik Gelişmişlik Sıralaması. (Erişim: 19.08.2016), http://politikaakademisi.org/2015/08/05/dunya-ekonomik-gelismislik-siralamasi/

Yıldırım, M. (2009). Modernizm, Postmodernizm ve Kamu Yönetimi. Uluslararası İnsan Bilimleri Dergisi, 6(2), 380-397.

Zemahşeri, Carullah Mahmud b. Ömer (1992). Esasü'l-Belağa, Daru'n-Nefais, Beyrut. 